\title{
From eco-catastrophe to zero deforestation? Interdisciplinarities, politics, environmentalisms and reduced clearing in Amazonia
}

\author{
SUSANNA B.HECHT* \\ Institute of the Environment, Luskin School of Public Affairs, University of California, 405 Hilgard Avenue, Los Angeles, CA, USA \\ Date submitted: 30 May 2010; Date accepted: 27 April 2011; First published online: 19 September 2011
}

\section{SUMMARY}

Brazil's rate of deforestation has declined by more than $70 \%$ since 2004 , a dynamic unimaginable even a decade ago. Even the worst drought in more than 100 years (2010) produced a flat clearing profile from 2009-2010, an unexpected result, since dry periods usually have clearing spikes. While deforestation continues throughout the tropics (and Amazonia), and the recent change in Brazil's Forest Code has produced a modest increase in deforestation, there are significant processes that are slowing clearing and fostering woodland recovery. This paper outlines the multiplicities and interdisciplinarities of political ecologies, policies, politics scientific approaches and technologies that have moderated forest conversion and shaped Amazonia's unusual, and unusually effective development and conservation conjunctures in Brazil's post-authoritarian period. New institutional framings, ideologies, political decentralization, globalizations and an expanded arena for new social movements and civil society provided the context for this transformation. Changing environmental institutions, discourses and the relatively redistributive social pact that underpinned President Ignacio (Lula) da Silva's administration had a significant role in promoting more resilient land uses, monitoring, compliance and new markets, while regional social movements and national and international commodity boycotts affected more damaging ones. Finally, other forms of payment for environmental services, such as REDD (Reducing Emissions from Deforestation and forest Degradation) and REDD+ are changing the value of standing forests. This paper describes how complex interdisciplinarities shaped the politics, policies and practices that slowed forest clearing. However, Amazonia's politics are extremely dynamic: destabilizing processes, violence and indifferent national leadership could still reverse this remarkable turnaround.

Keymords: Amazon, conservation, deforestation, forest transition, fragmentation, governance, interdisciplinarities, political ecology, REDD, socio-natures

\footnotetext{
*Correspondence: Dr Susanna Hecht e-mail: sbhecht@ucla.edu
}

\section{INTRODUCTION}

Brazil's deforestation rate has dropped by more than $70 \%$ since 2004 (INPE [Instituto Nacional de Pesquisas Espaciais/Brazilian National Institute for Space Research] 2011). Even Amazonia's 2010 drought, the most severe in more than one hundred years, did not affect the clearing decline, even though typically El Niño desiccations are usually associated with sharp clearing spikes (Meggers 1994; Siegert et al. 2001; Alencar et al. 2006; Cochrane \& Laurance 2008). Robust commodity prices, often correlated with high clearing rates, also seemed to have minor effects on the declining deforestation pattern (Vera-Dias et al. 2008). This paper examines the formation of politics, policy, practices and political economies, shaped by new interdisciplinary ways of thinking which have produced this surprising outcome. Amazonia is an unusual case, not just because lower deforestation rates were hardly imaginable even a decade ago. The changing deforestation profile is the result of multiple environmentalisms formed by local political economies, informed by differing scientific paradigms and managed by different political coteries, at different scales and articulated into global processes in different ways (Hecht 2011). These have produced synergies and regional complexities that can reinforce positive landscape trends.

As simple analytical categories, Amazonia can be seen to be composed of landscapes of 'Ür nature' (the 'wild nature' of classic conservation), 'Neo-natures' (the agroindustrial modernist landscapes where land is basically a substrate for silvo-industrial, agro-industrial or livestock production, involving total landscape transformation into what are essentially monocultures) and 'socio-natures' (socioambientalismo as it is called in Brazil and elsewhere in Latin America), the inhabited forested or mosaic countryside. These each embrace different discourses about the causes of deforestation, refer to different scientific regimes or theories of change, and vary in their approaches to land-use policies and practices. Each is also globalized as well as regionally embedded. But these changes in deforestation patterns cannot be understood without understanding the significant transformations in Brazilian environmental conservation that occurred at the end of the 20th century.

\section{Context}

Chico Mendes, who would become the symbol of Amazonian conservation and social justice, was assassinated in December 
1988, when Brazil and Amazonia were at the cusp of three massive transformations. The first was democratization of Brazil's political culture after 24 years of authoritarian rule. The rewriting of the Brazilian constitution in 1988 produced a dramatic shift in the nature of citizenship and in national political processes, with Brazilian society's most marginalized members asserting their political presence in land and social rights. This heralded a new, often uneasy and complex alliance between Brazil's social classes around governance and environment (Hochstetler \& Keck 2007; Hecht 2011).

Brazilian land law was changed in fundamental ways by Article 68 of the new Constitution. It assured the land rights of traditional peoples. This was crucial for recognizing land claims in forested areas, not just through 'effective use', which had historically meant clearing and underpinned a great deal of the explosive deforestation of Amazonian frontiers (Hecht \& Cockburn 1989; Fearnside 2001; Simmons et al. 2007), but by ratifying traditional institutional forms of natural resource access, governance and ownership, including tree tenure, traditional access, usufruct rights, and symbolic and historical claims over landscapes. This transformation reformulated Brazil's criteria for land tenure, which had not changed in most rural areas since the mid-1800s (Hecht \& Cockburn 1989; Alston et al. 1999; Wolford 2005).

The passing of Article 68 also expanded conservation concepts and practices, by asserting that inhabited landscapes could also function as conservation areas, a position at odds with the standard set aside, 'Ür nature' conservation models, derived from the USA's park system (Foresta 1991). This shift had deep implications, because it generated institutional alternatives for forest based populations, most of whom did not fit into colonist agricultural schemes and who were often expelled by classic 'wild land' preservation. Article 68 recognized the long coexistence of forest and people within Amazonia. The rise of what came to be known as 'socioenvironmentalism' forged an alternative rural development. Rather than simple yield efficiency or biodiversity set asides as the rationales for Amazonian occupation, it marshalled discourses of social justice, historical resilience, political autonomy and socioecological sustainability in forest landscapes, and fundamentally argued that much of what was understood as wild had a deep human footprint, as increasingly documented by Amazonian archaeologists and ethnographers (Erickson 2006). Socio-natures engaged different scientific paradigms, practices and political economies, producing working landscapes that differed from both the dominant modernization development models and classic conservation (Zoomers \& Haar 2000; Dandy 2005; Goeschl \& Igliori 2006; Kant 2009).

The second great transformation was the rise of Neoliberal and structural adjustment economic reforms, later modified by the Brazilian Workers Party's tropical Keynesianism. Economic restructuring initially followed the policies of the 'Washington consensus': relaxation of trade barriers, loosened restrictions on capital flows, enhanced international participation in national companies, at least partial privatization of state enterprises and a shift to greater market rather than state control of the structuring forces of the economy. This was also accompanied by the outsourcing of many state activities and civil services to firms and nongovernmental organizations (NGOs) (see Perreault 2003; Bebbington 2004; Almeida 2007; Irwin 2007; Baker 2009; Fortes 2009). Neoliberal trade reforms were crucial in the dramatic expansion of Brazil's soybean and livestock into global markets, nurtured by an aggressive export policy, but also played a key role in the emergent 'green' and 'social' markets and for non-timber forest products (NTFPs).

The Neoliberal reforms were overseen by President Fernando Henrique Cardoso (whose term lasted 1995-2003), and through credits and technology development that actively supported the high tech agro-industrial sector for both national and global markets. Cardoso also put into place an Amazonian secretariat and Amazon pilot projects, as the agro-industrial frontier and deforestation surged along the southern Amazon's 'arc of fire'. Brazil nudged into the top ranks of global commodity exporters (Hecht 2005; Jepson 2006; Nepstad et al. 2006b; Hecht \& Mann 2008). While the main beneficiaries of Neoliberal reforms were unquestionably larger export industries, the possibilities of international niche ('social' and 'green') markets were viewed as one of the arenas where small-scale producers or forest populations would have a competitive advantage (Brown \& Rosendo 2000; Dandy 2005; Hecht 2007; Brondizio 2008). Aggressive international export development programmes embraced global commerce. Brazilian minerals, iron ores, soybean and beef dominated international commodity markets, while Brazil's industrial portfolio, including aeroplanes, flex-fuel vehicles, electric and non-electric machinery, flooded global markets (Cardenas 2009). The Brazilian economy had a robust growth rate, hovering around 5\% during the first decade of the $21 \mathrm{st}$ century.

Neoliberal policies and the social dissatisfactions (and inequalities) they engendered, were such that they created a political platform that resulted in the overwhelming election of the Workers Party candidate and former Chico Mendes ally, Luis Ignacio 'Lula' da Silva, as President in 2002. Lula kept to Cardoso's Neoliberal macroeconomic approach, but also implemented strong redistributive practices (Baiocchi 2003; Domínguez \& Shifter 2008; Holston 2008). Lula also charted a new environmental direction with the first rubber tapper senator and Chico Mendes colleague, Marina Silva, as head of the Ministry of the Environment from 2003-2007, and an explosion of new socio-nature and conservation initiatives.

The third element of the new Brazilian context was the rise of the environment as a central element in the formation of Amazonian and Brazilian politics. A powerful critique of destructive Amazon development that had annihilated the livelihoods of traditional forest populations, the largely socially regressive outcomes that conventional development and conservation was producing, was joined to a sharp environmental appraisal of the effects of clearing on biodiversity, soils, hydrology and climate. The impacts 
of Article 68, structural adjustment and the socioeconomic critiques of the Amazon development model that unfolded from the mid-1960s to the early 1990s generated the scaffolding through which new Amazonian politics began to consolidate. These involved four environmental frameworks that surged onto the international scene in Latin America and forged an interdisciplinary analysis in which later policies and practices would be rooted.

The first trend was the globalization of environmental/ecological discourses that were associated with the rise of the environmental movement in the USA in the 1970s, and that later was internationalized via formal conservation organizations and multilateral development agencies in the mid-1980s. Next, the expansion of the international ecological sciences of the tropics through research institutes such as $\mathrm{La}$ Selva (Costa Rica), Barro Colorado Island (Panama), Luquillo (Puerto Rico), San Carlos (Venezuela), as well as Brazil's national Amazon institutions such as INPA (The National Institute of Amazon Research) and the Goeldi Museum, its space monitoring centre INPE and university programmes like NAEA (Núcleo de Altos Estudos Amazônicos; the Centre for Advanced Amazon Studies at the University of Pará). These institutions provided crucial information on the socioecological complexity, archaeology, historical ecology and biodiversity of tropical ecosystems, and began to monitor the effects and the magnitude of land-cover change.

Third, tropical research began to 'scientize' indigenous knowledge systems, cultural ecology, agroecology and 'alternative development', as anthropologists, geographers and agronomic scientists developed multidisciplinary skills for understanding ethnosciences. During the 'Big Project' planning eras of the 1970 s and 1980 s, conventional production models often failed, and failed to predict development impacts, while traditional systems showed sustained productivity and durability. This research was also crucial in documenting the degree of human manipulation of 'wild systems' and the detailed environmental history of the region (Posey \& Balée 1989; Anderson 1990; Rival 2002, 2006; Balée \& Erickson 2006; Erickson 2006; Heckenberger \& Neves 2009; Pinedo-Vasquez et al. 2011)

Fourth, 'big science' emerged; the large-scale study of climate underpinned the disquiet about deforestation in the late 1980 s, and became more salient and central to policy in the 1990s. The international LBA (large-scale biosphere atmosphere experiment) programme, led by Brazil with the aid of an international consortium of researchers from 1995-2004, provided a huge new body of data about forms of clearing and carbon budgets which would ultimately infuse development debates and provide the scientific foundation that would structure the new politics of environmental services. These four trends provided the interdisciplinary scientific 'legs' to underpin Amazonian politics.

New sets of actors in the socioenviromental movements, social concerns over distributional justice and both largescale and small-scale research affected the development debates (if not always the practices) of regional development and provided the intellectual arsenal to counter the earlier geopolitical and simplistic calculus of frontier planning. The widespread analysis of the effects of development went well beyond questions of economic efficiencies, and laid the groundwork for methodologies that would eventually become the foundations of ecological economics and political ecology (Hecht 1985; Schmink \& Wood 1987; Browder \& Godfrey 1997; Browder et al. 2008) Current Amazonian dynamics can be seen as an interaction between globalized processes, fairly active redistributional policies, more participatory forms of planning and a new structures of tropical development that pivoted on environmental concerns that reflects the interaction of these four environmental trends.

\section{Deforestation}

Chico Mendes was assassinated because he opposed forest destruction for both environmental and social reasons. Disillusionment with the state practices, and the rising importance of civil society and the politics of decentralization enhanced the role that local communities and NGOs were to play in the new politics of Amazonia (Hecht \& Cockburn 1989; Hall 1997, 2000). By Rio de Janiero's 1992 global environmental forum (URL http://www.un.org/geninfo/bp/enviro.html), future deforestation control was to be a Brazilian showpiece, but was marked by earnest words and little action due in part to the complexity of the processes that underpinned deforestation, the corrupt regime of President Fernando Collor and the incipient nature of environmental institutions at all scales as Brazil transitioned from authoritarian to democratic regimes. The multiple 'Ür', 'Neo' and 'Socio' nature coteries had different views of drivers of deforestation, policy and institutional configurations and a lack of a coherent coordination of their differing concerns.

Brazil's deforestation rates bounced up and down, with extensive fires associated with El Niño and drought years, exchange rate fluctuations and the investment dynamics of the national economy. Climatic oscillations compounded the deforestation trends associated with the expansion of the 'Neoliberal frontier' of mostly export soy and the burgeoning Amazon beef herd, as fires spread into adjacent forests, onto pastures and ignited degraded forests (Alencar et al. 2006; Arcand et al. 2008; Cochrane \& Laurance 2008). Clearing and burning expanded from Brazil's central west up through highway BR364, which had shifted from a violence plagued peasant frontier to the heart of Brazil's soy and beef agroindustrial export economy in areas where land tenure had been formally legalized (Ferraz et al. 2005; Hecht 2005; Jepson 2006a,b; Nepstad et al. 2006b; Ribeiro \& Verissimo 2007; Brannstrom et al. 2008; Browder et al. 2008; Fearnside 2008; Vera-Diaz et al. 2008).

Opening frontiers, such as highway BR163 from Cuiabá to Santarem, especially the central section, the 'Terra do Meio,' exhibited the usual 'clearing for claiming' and its associated violence, complete with expulsions at gun point 


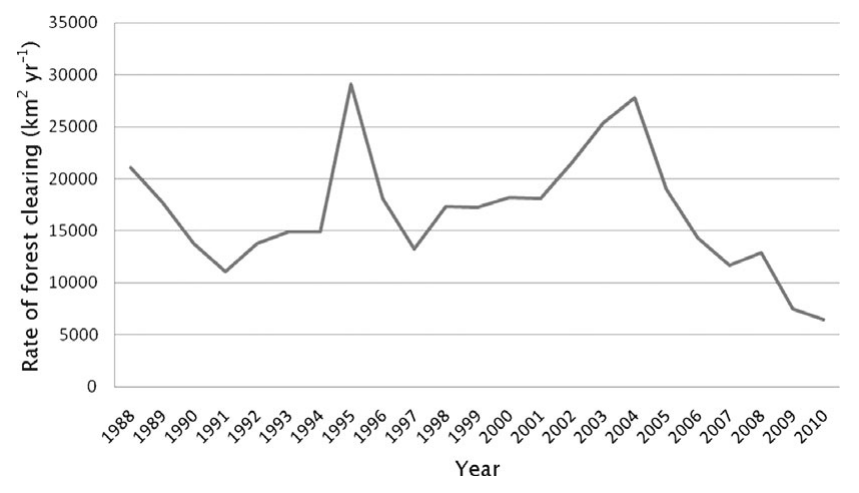

Figure 1 Annual rate of deforestation in Amazonia.

and assassinations (in this case, a 73 year old American nun, Dorothy Stang) in a region that did not lack for unsung environmental martyrs (Campos \& Nepstad 2006). This pattern of violence and threat continues with recent assassinations in May 2011. Between agro-industry and infrastructure, at the turn of the millennium Brazil was a global leader in deforestation, with an upward trend.

After 2004, a vertiginous drop in clearing seemed to be occurring, even as Brazil catapulted to the top ranks of the emerging economies. The idea of 'desmatemento zero' (no new deforestation) was bandied around as a credible option in Brazil's policy circles (Nepstad et al. 2009) and a cabinet position with the goal of zero deforestation was announced in May 2011. To understand this process, it is useful to look at some of the interdisciplinary socioenvironmental politics that shaped it. It is also important to keep in mind the vulnerabilities: there are significant structural, institutional and climatic instabilities in the drivers of forest clearing and forest protection, most recently the potential changes to the Forest Code, but the continuity of the downward trend in deforestation in spite of strong commodity prices, droughts and economic expansion, defy 'received ideas' about deforestation, and suggest the possibilities of structural change (Fig. 1).

\section{The politics of agreement}

How did this transformation come about and is it durable? First it emerged through the 'politics of agreement' where all the environmentalisms converged. These included science-based information on the magnitude and location of clearing, produced in timely and usable ways. These results were not always uncontroversial, but still provided an empirical baseline. With increasing technical sophistication, monitoring and geolocation became more precise, reliable and trustworthy.

Next, the reality and urgency of climate change became a national political concern. Brazil has long and brutal experience of periodic droughts associated with El Niño in north-east Brazil. These events have been scourges: socially disruptive and economically catastrophic. The impacts of drastic climate change and its diaspora are not abstractions in Brazil, but something within the cultural and historical experience of virtually everyone, if not directly than through migrants from the north-east, and the region's music and literature. The intensification of Niño cycles predicted by some models may have strong effects in Brazil, especially in its commodity producing Central West (Moran et al. 2006; Killeen 2007; Marengo et al. 2008; Villar et al. 2009). The severe droughts of 2005 and 2010 in Amazonia resulted in stranded populations, biotic die-offs and stressed forests, and provided an object lesson about the possible impacts of such change (Alencar et al. 2006; Moran et al. 2006; Baker et al. 2008; Brondizio \& Moran 2008; Marengo et al. 2008; Malhi et al. 2009; Lara \& Cohen 2009; Asner \& Alencar 2010; Galbraith et al. 2010; Lewis et al. 2011).

Third, all the sectors ('Ür', 'Neo' and 'Socio' natures coteries) agreed on use of regulations like the Forest Code, and the use of state powers and institutions (such as IBAMA [Instituto Brasileiro do Meio Ambiente e dos Recursos Naturais Renováveis/the Brazilian Institute of Environment and Renewable Natural Resources] and state agencies) to enforce deforestation laws. Theory often failed in practice, and IBAMA agents were often corrupt, but the principle was in place, and enforcement has improved. Fourth, local social institutions and decentralized strategies at municipal and state levels were supported in reducing forest clearance. Finally, market mechanisms were mobilized to enhance alternatives to clearing, ranging from intensification of agricultural production, agroforestry and NTFP development, and payment for environmental services (PES). These convergences represented a kind of 'thickening' (an expansion in density and capacity in social networks) of civil society and the development of new forms of institutional engagement. This does not suggest that areas of procedure, nor that questions of power or forms of development were conflict free, but rather that the 'rules of the game' were substantially agreed upon.

\section{CONTROLLING DEFORESTATION IN AMAZONIA: THE POLITICS OF MULTIPLE ENVIRONMENTALISMS}

During most of the 1980s and early 1990s, concern over deforestation centred on the issues of biodiversity loss, sustainability of land uses replacing forests, and the social inequalities engendered by the regional development model with credit lines, violence and speculation still driving much of the clearing (Hecht \& Cockburn 1989). By the late 1990s and the Kyoto accords (URL http://unfccc.int/resource/docs/convkp/kpeng.pdf), the questions of emissions and climate change were far more visible on the political and scientific landscape. With roughly $75 \%$ of Brazil's carbon emissions derived from deforestation, its control had become central to Amazonian development politics for each of the environmentalisms (de Araujo et al. 2009; Fearnside et al. 2009) and for Brazil's international 
prestige. Given the emphasis on controlling deforestation in Brazilian climate policy, how did the varying approaches to controlling deforestation play out in the context of the Brazilian environmentalisms?

\section{Conservation set asides and the fragmented forest}

In the evolution of conservation science in Amazonia, scientists have integrated modelling, biogeography and remote sensing as ways to predict patterns of diversity for setting priorities for large-scale set asides (Mittermeier et al. 1998; Pennington et al. 2006; Soares et al. 2006; Mittelbach et al. 2007). Focusing on 'hot spots' (areas with high endemism and significant human threats), international groups, such as the World Wildlife Fund (WWF), Conservation International (CI) and The Nature Conservancy (TNC) moved aggressively to demarcate reserve areas (Myers et al. 2000; Killeen et al. 2007). This approach was reinforced increasingly by the decades long scientific enterprise known as the Minimum Critical Size study (now known as the Biological Dynamics of Fragments Project), based in Manaus (Laurance 2002, 2007; Laurance et al. 2002a,b; Lewis et al. 2009). This research approach was informed by the extinction models elaborated in the classic analysis of island biogeography but later substantively modified through the study of the ecology of forest fragments (Laurance 2008). The programme produced a flood of studies on fragmented ecosystems that were effectively marshalled for the creation of largescale set asides, since fragment decay, species declines, local extinctions, mortality and changes in forest structure, microclimates and windfalls accelerated with smaller areas (Peres 2005; Barlow et al. 2006; Laurance 2004, 2007; Lees \& Peres 2006). This research, along with hot spot analysis, provided scientific inputs into the politics and policies of set asides, particularly for conservation NGOs like WWF, Conservation International and The Nature Conservancy. The research helped produce a pulse of set asides funded in part by international NGOs and contingent lending to nation states, and added millions of hectares to Amazon conservation areas even as this generalized approach became an issue of bitter conflict worldwide (Hecht \& Cockburn 1989; Neumann 1998; Schwartzman et al. 2000a, b; Sanderson et al. 2002; Dowie 2009). Today c. $7.76 \%$ of Amazonia (44 624651 ha within 110 parks and biological reserves) are subject to Protecão Integral (complete protection), compared to the slightly more than 10 million ha in 23 parks that existed in 1985. Most protected areas were created during the 21st century under the leadership Lula and Marina Silva, with many reserves created in areas of active transformation as opposed to the less controversial 'parks at the end of the world' approach that had previously prevailed (Foresta 1991). Thus development processes of all types would have to confront and obey conservation limits in active frontiers.

However, set asides did not always protect landscapes since the capacity to supervise designated areas often made them 'paper parks' and targets of exploitation and local resistance (Schwartzman et al. 2000a; Peres \& Zimmerman 2001; Hayes 2006; Nepstad et al. 2006a; Ribeiro \& Verissimo 2007; Joppa et al. 2008). The problems of the set asides, the pressures from forest-based social movements, and the empirical demonstration of the physical integrity of inhabited versus 'empty' parks, produced the emergence of sets of 'sustainable development reserves', including extractive reserves, those of traditional peoples (like quilombos [fugitive/former slave settlements] and lake populations) and indigenous reserves. This reflected a broader shift in the historical understanding of Amazonia, the impact of research about the sustainability of such systems, and echoed the larger global shift in devolution of tenure to forest populations (Kant 2009).

\section{The social forest: reimagining the matrix}

The political ecology of traditional peoples offered a perspective on forests rooted in the politics of social justice and sustainability science. These approaches were complemented by the rise of matrix, landscape and historical ecology, which focused on the nature of the 'matrix' (the area between old growth fragments) as critical to the replenishment of 'Ür' forests, as well as support of local and inhabited landscapes. These researchers concentrated less on the dynamics of extinction within a single fragment (the emphasis of fragment ecology) and more on the processes of the physical and ecological structure of the matrix that enable immigration through such systems for support of biodiversity at the meta-population level. The focus was rooted in long-term studies of agroecology, successional and landscape ecology and traditional production systems (Fleishman et al. 2002; Perfecto et al. 2007, 2009; Hanski 2009). These emphasized complex anthropogenic landscapes of modern indigenous groups like the Kayapó, Huaroni, Ka'apor and Kuikuru, and thoroughly documented how historical ecologies and modern farmer/extractor landscapes throughout Amazonia structure the matrix in species-diverse complex ways (Posey \& Balée 1989; Padoch et al. 1999; Pinedo-Vasquez et al. 2001; Rival 2002; Bray et al. 2004; Balée \& Erickson 2006; Erickson 2006; Sears et al. 2007; Heckenberger et al. 2008; Hecht 2009). In Amazonia, the calibre of these domesticated landscapes was such that biological reserves, analysed by remote sensing and rapid biodiversity appraisals, were often placed in territories that had been managed by native peoples, or traditional forest dwellers, like quilombos or former slave refuges, for hundreds of years (see for example Acevedo Marin \& Castro 1997). Indeed, early parks were regularly overlain on indigenous lands (Foresta 1991). Modern data, coupled with major archaeological discoveries (such as anthropogenic soils and large areas of geoglyphs, huge geometric earthworks, in areas of 'untrammelled' forest) recast both the understanding of past occupation and modern day potentials (Lehmann et al. 2003; Glaser \& Woods 2004; Parssinen et al. 2009; Woods et al. 2009). Thus, a new social ecology, informed by matrix, agroand historical ecology and carbon science, began to inform 
Figure 2 Deforestation trends in Amazonia 2008-2010.

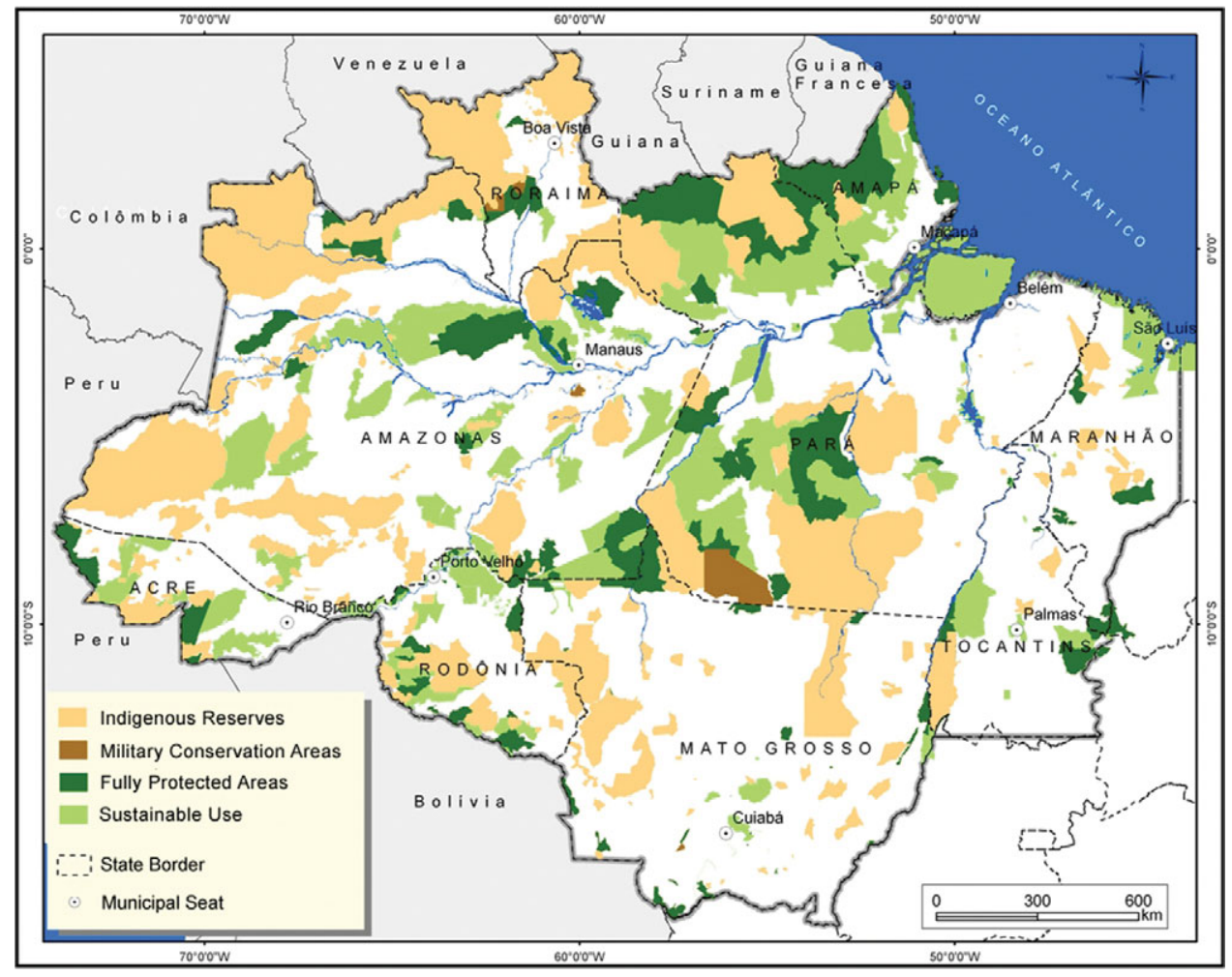

management and sustainability in regional development and in environmental debates. The influence of the quality of the matrix could have decisive conservation outcomes. Between agroforestry, landscape management and anthropogenic soils, traditional knowledge systems of all types gained prestige.

This idea was translated into Brazilian conservation policy. About 20\% of the Amazon is currently in indigenous reserves, and in Amazonia there are some 70 extractive reserves and 19 sustainable development reserves, comprising over 15 million ha. In addition to these areas, there are a number of other categories of protection permitting sustainable use, involving a further 65 million ha. Thus $>40 \%$ of Brazilian Amazon land is subject to some form of protection, $60 \%$ of this in conservation units managed by local populations. The rapid protection of forested lands is unmatched anywhere else in the tropics, and reflects the powerful political pressures for inhabited landscapes exerted by social movements, their national, international and government allies, and the globalized framing of these kinds of inhabited conservation units in terms of human rights, environmental justice and forest sustenance, and powerful arguments made by the scientific community about the resilience, sustainability and value of these humanized ecosystems. The politics of forest landscapes produced new land management institutions that also coalesced in a shift from state tenure to a complex of new regimes, many underpinned by Article 68 of the constitution, and shaped Amazonia's conservation map to one where inhabited landscapes and reserves dominate the forms of protected areas (Fig. 2).

\section{The globalized arc of fire}

Both Ür and socio-natures involved landscapes that retained a largely woodland character, and contrasted profoundly with the landscapes of agro-industrial modernization, where the production was maintained by an intense agronomic technology treadmill. The arc of fire, or arc of deforestation on the southern flank of the Amazon exploded into flames as areas comprising both transitional forest and cerrado became 'sacrifice zones' largely to the globalized soybean and burgeoning livestock sector (Hecht 2005; Jepson 2006a; Nepstad et al. 2006b; Fearnside 2007; Brannstrom 2009).

The soy frontier represented an entirely new kind of regional economy: it was completely globalized in its technological norms, marketing and the discipline of its production practices, and represented a successful transformation of native vegetation and landscapes into substrates for highly intensified agro-industrial monocultures which, as the global and domestic demand for soy soared, rapidly expanded over the landscape as Brazil became the main global producer of soybeans. The explosive rates of clearing, the maturing of IBAMA, the expansion of Brazil's remotesensing capabilities, and regional social movements coalesced in the ability to better monitor clearing and to accurately geolocate land ownership data. As global outcries over the deforestation arc increased, Mato Grosso came under intense scrutiny. The control of deforestation in Mato Grosso was not merely a matter of monitoring, but also emergent forms of governance. 


\section{GOVERNMENTS, GOVERNANCE AND GOVERNMENTALITY}

\section{Seeing like a state: the new tropical panopticon}

In Mato Grosso, the sites of explosive clearing of the soy frontier, the government of soy tycoon Blairo Maggi and The Nature Conservancy developed a deforestation 'panopticon' of remote sensing, geopositioned holdings and ownership data to monitor legally-mandated forest conservation on private property (hills, water courses, head waters and required forest reserves). The logic for this approach was partially due to international boycotts for 'rainforest soy' and 'rainforest beef' (which I discuss in more detail later) and the importance of green branding and its premium pricing, but other factors were involved. First, there were the real concerns about climate change voiced by the politically powerful Maggi, supported by the research of Brazilian and international scientists, and in national policy. These were complemented by various agro-ecological efforts directed at soy ecosystems and the rise of ongoing researcher-grower organizations dedicated to 'soya sustentável'. This intensified scientific scrutiny of the region, whose transition and cerrado forests had been neglected in favour of monitoring high biomass Amazon forests (Klink \& Machado 2005; Brannstrom et al. 2008), and helped stimulate the use of maturing surveillance technologies for Forest Code compliance and to track fires and emissions. This was a command and control form for observing of legal norms, enabled by surveillance technology.

Another issue pertained to state governance itself: did local states have the capacities to rule in Amazonia? If the Amazon, with its 500 years of legendary lawlessness, could be brought under the aegis of national legal systems implemented in regional states with exploding economies, then a new phase of nation building would have been achieved, and the elusive goal of conservation and development could actually be realized in Amazonia. A final issue, which lurked on the horizon, was payment for reduced deforestation and other types of environmental services. Unlike remote forested areas, soy growers could provide explicit figures for the opportunity costs of not clearing (Borner \& Wunder 2007). Forests in the arc of fire began to be viewed through the lens of environmental opportunities, and speculation on standing forests rather than cleared lands was now imaginable.

Clearing was thus no longer an absolute necessity for land claims, but this hardly meant that land conflicts evaporated. Amazonia hosts a range of tenurial regimes from fully private to an array of collective forms, from the residue from colonial sesmarias to today's agrarian reform settlements. There are earlier and overlapping forms of land tenure, like tree tenure, municipal claims, sesmarial and other historical rights, and multiple jurisdictions between national agencies and local land offices (Bunker 1985). In Amazonia's recent turbulent history of violent occupation, speculation and fraud, at least one third of the Legal Amazon land holdings in private claim (some 158 million ha) still remain to be finally verified by the Brazil land agency INCRA (Instituto Nacional de Colonização e Reforma
Agrária) (Imazon [Instituto do Homem e Meio Ambiente da Amazônia] 2008). Although the tenurial institutionalities were improved compared to the explosive periods of the 1970s, 1980s and much of the 1990s, the region remains disturbed by land and resource conflict, and the violence that attends it (Alston et al. 1999; Zoomers \& Haar 2000; Simmons 2004; Aldrich et al. 2006; Simmons et al. 2007; Araujo et al. 2009). Indeed, land and environmental conflict have claimed the lives of more than 1150 activists over the last 20 years, according to the Catholic Church's Pastoral Land Commission (CPT [Commissão Pastoral da Terra] 2010) and five peasant environmental leaders were killed in May and June of 2011.

\section{Governmentality, environmentality and the creation of environmental citizens}

'Governmentality' is a Foucauldian term which refers to 'the conduct of conduct' (Foucault et al. 1991; Dean 2010), and when this idea is used in environmental politics, as it increasingly is, it discusses how policies of greater decentralization and participation are new 'technologies' of government. As Agrawal (2005) pointed out, these must 'redefine political relations, reconfigure institutional arrangements and transform environmental subjectivities'. $\mathrm{He}$ posited the term 'environmentality' for addressing this transformation in environmental governance. For decentralization and devolving state authority to be successful, there must also be shifts in the subjectivities and in the sense of self of those who are actually both governing resources and being governed. Simple appeals to utilitarian ends or coercive threats will not work in these new contexts. Environmental sensibilities embodied in traditional knowledge systems were already a feature of many Amazonian inhabitants, but the transformation to 'environmentality' on parts of TransAmazon threatened by a speculative frontier reveals the emergence of this new type of governance, now a much wider process. A technified centralized land-monitoring management model on a globalized agro-industrial landscape like that of the soy zone of Mato Grosso is one thing, but in some of the less domesticated parts of the Amazon different processes were at work, shaped by social movements and associations. The classic story in this regard was the triumph of the rubber tappers and forest peoples' movement in Acre (Hecht \& Cockburn 1989), but violent expulsion has been the norm with deadly outcomes (Treccani 2007).

New forms of governance, such as environmentality, remain most dramatic on the turbulent frontier where the TransAmazon meets highway BR 163, the road that that connects Cuiabá with Santarem in the violent Terra do Meio, or the middle lands. Farmers were organized through an agrarian/socio-forest politics that emphasized producer and community associations for access to credit, extension and other state programmes rather than rural individuality, and produced surprising outcomes. 
Marina Campos has described how the Movement for Survival on the TransAmazon and Xingu (MSTX), an NGO umbrella group with some 20000 members and more than a hundred grassroots organizations, observed the turbulence associated with ranchers, speculators and land grabbers moving up the BR163, and began to think in a 'regional way' (Campos \& Nepstad 2008). By the late 1990s, MSTX launched the idea of large regional forest reserves to both moderate the local climate and buffer their TransAmazon frontier from the aggressive speculative 'New Frontier' of ranchers and illegal loggers that was pushing up toward them from the south. Through participatory planning processes, involving community groups, natives and extractors, government at different scales, activist scientists and NGOs ranging from the Catholic church to Greenpeace, these farmers developed a general regional plan, formed of a mosaic of land uses from annual crop agriculture to inhabited and native reserves to classic conservation set asides. By November of 2004, two extractive reserves of some 2 million ha were in place along the TransAmazon frontier. When Dorothy Stang was assassinated, Minister of the Environment, Marina Silva and President Lula rapidly designated another 3 million ha of forest preserve, and moved the military police in to restore order and to investigate the murder. A presidential decree prohibited the emission of titles and logging permits in order to stabilize the region. This case involved a socioenvironmentalism focused on regional strategies to assure farmer livelihoods and those of traditional peoples, but within a complex ecological matrix. This new landscape mosaic marked an important new trajectory in Amazonian regional planning, where local populations and social movements have emerged as significant actors in creating new types of institutional frameworks, political practices and ecologies, and engaged in collective environmental action powerful enough to reshape the structure of the landscape (Campos \& Nepstad 2008). This went beyond the usual 'agrarian environmentalism' (Guha \& Martínez Alier 1998) into a regional environmentality, including protected reserves, extractive economies and active agricultural ecologies. A similar dynamic of regional thinking and collective governance in advance of development thrusts and speculative frontiers is also occurring at the international border of Brazil, Peru and Bolivia as the TransOceanic highway proceeds. The MAP (Madre de Dios, Acre and Pando) process, like the Xingu initiatives, reflects a blending of state, social movements, NGOs and scientists crossing borders of nations and disciplines to advance a durable regional development model. (Perz et al. 2008).

\section{Cowboys and Indians}

Another very recent and unusual example of emerging 'environmentalities' involves the new fire brigades composed of indigenous populations (Kayapo and Xavante) and ranchers that are taking on fires in Mato Grosso. The questions of fire and Amazonian forest degradation have a long history in Amazonian development debates (Nepstad et al. 2001; Hoffmann et al. 2003; Balch et al. 2008), but uncontrolled or escaped fires destroy agricultural and physical infrastructure, and sub-canopy fires negatively affect standing forests. Stimulated by the NGO, Aliança da Terra and with intensive training from the US Forest Service, these multicultural brigades, formed of historically bitter enemies, represent a collective management solution to one of the region's most destructive processes, uncontrolled burning, and, in 2010, 22 fires were controlled. This system of informal governance is now set to expand into other areas surrounding the indigenous Xingu Park, to potentially combat fires in some 13 million ha of forest on both indigenous holdings and private properties. This new forest 'fire regime' represents an evolving form of environmentality and solidarity.

\section{FROM GREEN HELL TO GREEN MARKETS?}

\section{The cattle question}

Democratization and political openings were producing one dynamic of forest protection, but globalization of Amazonian commodities was generating other outcomes. Soy production, though dramatic, involves $<7 \%$ of the Amazon clearing (Fearnside 2008; de Araujo et al. 2009). The central issue for deforestation remains the livestock sector. Brazil's cattle herd has expanded to over 200 million head, of which more than 74 million reside in Amazonia. Brazil has become the largest global meat exporter, controlling some $44 \%$ of the market, and generating US\$ 5 billion in export revenue. While the technical parameters have improved (better vaccination, hoof and mouth-free areas and better techniques of pasture recuperation), the international markets and demand for beef will continue to drive this form of Amazonian deforestation in spite of regional soy and animal production intensification (Nepstad et al. 2006b; Morton et al. 2008)

Ranching continues to be desirable for producers because of its continuing role in land claims in speculative frontiers, money laundering from clandestine economies, property consolidation in some 'post' frontiers, its flexibility as an investment strategy, and its low labour requirements, low technical parameters, limited management regimes and low entry costs (Hecht 1993; Mertens et al. 2002; Pacheco 2009b; Walker et al. 2009). Compared with other land uses, ranching remains profitable due to the relatively low prices of land, technical improvement in genetic selection of pastures, and the set of institutional rents enjoyed through credit and extension, the cost savings coming from infrastructure development and the development of Amazon abattoirs, of which 73 of the 91 in Amazonia came into production in last 20 years (Walker et al. 2009). Cattle ranching also carries the symbolic values of masculinity, the lustre associated with the heritage of Hidalgos in Iberian traditions, and ranches are often a weekend country home for urban professionals.

Classic market signals can be unclear in many livestock systems due to the array of economic, managerial and 
cultural benefits, portfolio flexibility and the continuing potential for institutional rents. The association of pasture with roads, its linkages to increasing inequality in tenure and the numerous land conflicts triggered by its expansion exhibit the characteristics of primitive accumulation in Amazonian peripheries (Hecht 1993; Futemma \& Brondizio 2003; Araujo et al. 2009; Ludewigs et al. 2009; Pacheco 2009a; Walker et al. 2009) and have underpinned much of the regional land conflict. For smallholders, livestock remains a low labour activity in their production portfolios and, as annual crop prices have declined, economic returns have held for livestock. Ninety-five per cent of smallholders on consolidated Amazon frontiers have cattle (Ludewigs et al. 2009; Pacheco 2009a).

However, there are several counter pressures at work. The first set of these is 'spatial policy': the adoption of 'forest based development approaches' as part of state policy in Acre, Amazonas and Amapá constrains investment credits for large-scale livestock, giving these states low deforestation profiles. Further, the dynamic of livestock expansion has been controlled to a degree by conservation set asides and by the creation of reserves in frontier areas where this land use might otherwise have expanded. Third, there is more effective (though still imperfect) deforestation monitoring to control illegal pasture development through satellites and community, and regional-level organizations like MSTX. Finally, areas of most explosive deforestation and illegality were 'black listed' for cattle credits and subjected to heightened monitoring.

National and global market interventions, such as beef boycotts and purchasing moratoria for Amazon-sourced animal products, were also initiated in late 2009 by the fourth largest global beef trader Marfrig, as well as global purchasing groups such as WalMart, Carrefour, Nike, Clarks and other beef and leather buyers. With the new politics of supply chains, suppliers in some regions in the arc of fire, such as the Lukas do Rio Verde region, are positioning themselves in the national and global market as 'non-deforestation' soy and beef producers because of the age and location of their community (the region was deforested 25 years ago), and their expanding monitoring system that permits a 'green' certification for 'zero deforestation' holdings, alluring to USA and European buyers.

Transitions from pasture to other uses have generally followed four patterns: land abandonment, replacement by high value annual crops (soy rotations), substitutions by subsidized tree plantations such as oil palm and eucalyptus (all large-scale landscape interventions) or high value agroforestry, such as açai, cacau and coffee, increasingly important smallholder options (Brondizio 2008; Ludewigs et al. 2009).

\section{Globalization of Amazon taste}

Perhaps the most dramatic story of green marketing has been the explosion of açai, also known as tropical palmberry, an Amazonian traditional food now found in supermarkets throughout the USA. Urban and international demand for this antioxidant 'superfood' produced a surprising shift from annual crops and pasture to açai production. The açai agroforestry economy occurs largely in the lower Amazon, where an increase in forest cover and an expanding economy closely linked to forest resources, as national and global demand expanded into niche health food and social sustainability markets. Rather like biodiversity friendly coffee and cacau, açai was able to tap into new market segments (IBGE [Instituto Brasileiro de Geografia e Estatística] 2007; Brondizio 2008; INPE 2008) Thus, in the environs of Belem, an area with a 400-year history of deforestation, where increased population densities may be expected to enhance clearing, demand for forest products has produced a regional and globalized food commodity rooted in the cultures, tastes and forests of Amazonia, and is 'green' by its nature and production systems, not as an add-on or certification ploy.

\section{The REDD+ and the green}

The dynamics of Amazon forest economies will also be shaped by markets for forest environmental services. Amazonia's forests store significant amounts of the planet's carbon stocks, some $21737 \times 10^{6}$ tonnes (Saatchi et al. 2007). Global deforestation produces 12-20\% of global greenhouse gases (GHG), about equal to the emissions from the entire global transport sector, with Amazonia generating some $27 \%$ of this (Hirsch et al. 2004; Potter et al. 2009; Tollefson 2009). The loss of forests as a GHG sink and their conversion to a large source of atmospheric emissions also creates a third problem in that deforested lands modify surface conditions (albedo, roughness and water storage) that mediate weather patterns and larger climate dynamics, making clearing problematic at the level of local and regional atmospheric physics.

The initial REDD (Reduced Emissions from Deforestation and Degradation) proposal grew out of the Brazilian forest activist and scientific community, and focused less on offsetting $\mathrm{CO}_{2}$ from existing emitters (the politics of the Kyoto Accords) and more on avoiding emissions from deforestation by maintaining forest sinks in conservation holdings and in inhabited landscapes. The emphasis on the value of landscapes as carbon sinks was already emerging in carbon offsets in the earlier rounds of the Kyoto accords. The critique of the political economy these offsets was that the monetary value of carbon was speculative, and that the proposals did not require the first world to change its behaviour: it would buy itself out of global obligations. The value of offsets would be determined by willingness to pay by the emitter (a 'polluter pays' externality model) essentially allowing the developed world to define the terms of carbon trade. Other issues were that if natural forests were controlled or actually purchased by conservation groups, like The Nature Conservancy, the property rights for conservation carried with them the potentially lucrative 'derivatives' of carbon trading, turning what had often been promoted as a moral exercise in planetary altruism for saving biodiversity into 
speculation on real estate derivatives. Problems of 'carbon forest' enclosures could potentially enhance land conflicts (and indeed this remains a central problem) and increase regional inequalities, in spite of local hopes for using such funds for poverty alleviation (Wunder 2008; Borner et al. 2010; Okereke \& Dooley 2010; Singh \& Padung 2010). The lessons from some early schemes were problematic: the degree of GHG absorption was overestimated, there was 'leakage' (deforestation merely continued nearby), traditional inhabitants were relocated, there were management and oversight controversies and land conflict (Greenpeace 2009).

Other concerns emerged about 'carbon cartels' based in the international conservation organizations that would be paid for sub-national forest set asides on a 'by project' basis, producing an incoherent topography of corporate conservation of $\mathrm{CO}_{2}$ offsets (Greenpeace 2009). The 'Belém Letter', drafted by Brazilian social movements before the 2009 Copenhagen Conference, rejected REDD initiatives as they were currently structured because: (1) native forests and plantations were considered the same; (2) the problems of land distribution and tenure remain unresolved; and (3) the political economy of the initial language 'favoured economic actors that have traditionally destroyed forests'. At an epistemic level, the extension of markets into air and forests as a model of development was rejected in favour of 'solidarity economies', protected commons in a context of agroecologies and restructured agrarian systems. It was signed by Friends of the Earth and 40 other organizations (www.ecosocialistnetwork.org/Docs.htm).

The sums involved in carbon markets are substantial: US\$ 124 billion in carbon transactions occurred globally up to 2009 , a volume that eclipsed the paltry US\$1 billion for conservation. The estimated costs of REDD+ (the modification to REDD that emphasizes communities, includes the role of conservation, sustainable management of forests and enhancement of forest carbon stocks; see URL http://www.unredd.org/AboutREDD/tabid/582/Default.aspx) were modelled at a nominal rate within the current carbon markets of US\$ 7-18 billion over thirty years, reducing GHG emissions by some 6 billion tonnes (Nepstad et al. 2009). An institutionalized financial stream or 'rent' from carbon was certainly interesting to many tropical landholders and organized communities with substantial forest holdings (PointCarbon 2009).

REDD+ was widely viewed as a means to generate development funds at national and regional levels. Brazil is now committed to REDD+ through international donations carbon markets and official markets after 2012. REDD models are in the process of developing the institutional forms, financing, monitoring, on ground norms and capacities. Brazil has emphasized a potential array of capital flows, including the Amazon fund (US\$ 1 billion, supplied by Norway, but intended to initiate transfers from other first world emitters), funding for REDD from global sources, such as the states of California and Wisconsin (although the fiscal crises of these states have put these programmes in question), NGOs, foundations, the World Bank's Global Forest Alliance, existing national development funds and programmes, such as the subsidies from the national programme of the Bolsa Familial (a subsidy to poor households), new 'Fundos Verdes' (green funds) or Fundos Socioambientais (socioenvironmental funds), regional development programmes, such as Proambiente, and offset markets. The overall strategy includes large landowner and smallholder REDD+ approaches as part of Brazil's national climate plan (Governo do Brasil 2007, 2008), which involves international transfer of funds for environmental services of biodiversity conservation and GHG uptake provided by tropical forests. These types of payment would apply to ' $\ddot{\mathrm{r}}$ ' and 'Socio' natures.

The second element of the Brazilian government's climate approach involves payment for development opportunity costs. In Brazilian climate politics, those who benefited most from emissions historically need to compensate countries that will not be able to profit from forest replacement activities. This then would be the system that would apply most directly to compensation and control of deforestation in 'Neo' natures. Since the first world generated an enormous externality in global climate change, technology transfer and adaptation funds should be developed to assist countries in mitigating the effects of, or adapting to, climate change. This last would probably be most focused on the varying socio-natures.

\section{REDD+ pilot projects}

The Brazilian Climate Plan places REDD+ in a context of development investment funds. Currently, two programmes are being implemented: ProAmbiente (Hall 2008), involving 11 growth poles (one in each Amazon state) and $>4200$ families, and the Bolsa Forestal pilot project in the Juma Reserve, Amazonas. These represent a significant policy innovation for small farmers, who had been largely abandoned once they had arrived in Amazonia.

Proambiente, a central government programme, provided limited fiscal incentives (US\$ 325 per household), livelihood support and the development of physical and human capital infrastructure, in exchange for environmental services associated with land-use changes that reduced deforestation, enhanced carbon uptake, provided biodiversity support and reduced forest fires. The project suffered from several problems of a legislative nature and, at the time of its implementation (2000), a dearth of funding, a lack of technical support and problems in paying participants, in short the institutional deficiencies typical of 'peasant projects' in Amazonia (Hall 2008; Pacheco 2009a). Yet these issues can be overcome with time, and some of the problems were due to lack of legal frameworks and dedicated credit lines that now exist.

Amazonas state embarked on a different track with the FAS (Fundação Amazonas Sustentável). The intention was to use its extensive forests and minimal clearing as part of the REDD+ mechanism, and develop funding systems 
through the FAS foundation that would be independent of the vagaries of central government budgets. FAS's showplace project is the Juma reserve, c. 589612 ha located on the Madeira river and transected by highways BR319 and AM 174. Simulations indicated that $75 \%$ of this area is under threat of clearance (Soares et al. 2004; Stickler et al. 2009). This project uses the approach of the Bolsa Familia (in this case the FAS-funded Bolsa 'florestal' to subsidize income, education, scientific education and monitoring) to reduce deforestation, for poverty alleviation and community development. If successful, the project would ultimately save $>253$ million tonnes of carbon. This project has well-developed scientific baselines and involved researchers from the main Amazon research institutes. It is overseen by a ecologist, Virgilio Viana (currently General Director of FAS). Questions remain about scaling up such efforts, but this project has now developed a methodology applicable to other situations.

The approach envisaged in the climate model is dynamic and, in the medium term, the array of activities could enhance the matrices between different types of forest fragments in industrial landscapes, inhabited forests and old growth conservation areas, with the inhabited landscapes of Amazonia providing a new complex ecological geography of development, on which might well hang, not just the fate of Amazon forests, but now the future of the Earth itself.

\section{FINAL THOUGHTS}

It may be tempting to simply state that as Brazil has become richer it is experiencing a 'forest transition', a pattern of greater forest cover echoing the Euro-American model of economic modernization and urbanization that reduced pressures on forest resources. This model overlooks many profound differences between the Euro-American experience and that of the tropics (Hecht 2004, 2011; Perz 2007), and typically focuses on the dynamics of forest recovery rather than control of deforestation. A related idea is the Environmental Kuznets curves (EKCs), generalized ' $U$ ' curves of environmental improvement associated with increased gross domestic product (GDP) as natural resource dependency declines, production techniques and the composition of the economy shift, and the components of 'ecological modernization', such as more efficient use of resources and a rising ability to pay for environmental infrastructure improvements (like potable water) and regulations. The term has largely been discredited in many natural resource analyses because of the much larger ecological footprint associated with rising consumption associated with increasing wealth (CavigliaHarris et al. 2009; Mills \& Waite 2009). EKCs have been applied to deforestation, focusing on endogenous features of the nation state, including population, population density, GDP, debt, institutional configurations to test whether the curves exist and at what per person income level the inflection point (the place where environmental trends shift in a positive direction) occurs (Baker 2003; Cole 2003; Bhattarai \& Hammig 2004; Caviglia-Harris et al. 2009). The results of the EKC deforestation models are contradictory and often not supported by empirical work. Data from 35 countries showed no relationship between country wealth and forest conservation (Mills \& Waite 2009). Critics of EKCs point to problems with the data, the diversity of forest types that were used in the analysis (which often have divergent clearing processes), policy environments, institutions, forms of governance and comparability between countries (Grainger 2008).

In the case of Amazonia, development under authoritarian capitalism was highly destructive, and dramatic changes in political and economic contexts, legal frameworks and land institutions were required, framed by significant technical, institutional and scientific innovations. Active social movements and the institutions of civil society and legal protections were also required. Central to the processes were a diversity of environmentalisms, complex discourses about environment and equity, and increasingly globalized mechanisms of finance. Changing deforestation patterns, the product and the point of policy and institutional innovations were informed by deep interdisciplinarities, rather than an ancillary 'by product' of modernization. Amazonia's politics will always be contested but, for the moment, Brazil seems to embody the phrase of Chairman Mao: 'Where do good ideas come from? Do they fall from the sky? No they come from social practice'.

In spite of the optimistic trajectory of the last years, there remain profound instabilities. The recasting of the 1965 Forest Code in May 2011 suggests new political alliances at all levels may be recasting Amazonia as a purely economic frontier. The explosion in violence against rural activists further suggests that Amazonia is entering a new period. The ultimate fate of the Belo Monte dam on the Xingu, which has been the object of continuous protests by native populations since the 1980s, still remains an open question, as does the Madeira River Dam project. The recent purchase of more than 20000 ha of agricultural lands by Chinese investors and production contracts to numerous grain producers to assure supply in a context of historic droughts in China suggests that the terrain of Amazonian development is more dynamic than ever, and that the array of social pacts, new institutions and new forms of landscape conservation are about to experience strong pressures.

\section{References}

Acevedo-Marin, R. \& Castro, E. (1997) Negros do Trombetas. Belém, Brazil: UFPA.

Agrawal, A. (2005) Environmentalities. Durham, NC, USA: Duke University Press.

Aldrich, S.P., Walker, R.T., Arima, E.Y., Caldas, M.M., Browder, J.O. \& Perz, S. (2006) Land-cover and land-use change in the Brazilian Amazon: smallholders, ranchers, and frontier stratification. Economic Geography 82: 265-288.

Alencar, A., Nepstad, D. \& Diaz, M.D.V. (2006) Forest understory fire in the Brazilian Amazon in ENSO and non-ENSO years: area burned and committed carbon emissions. Earth Interactions 10: 1-17. 
Almeida, P.D. (2007) Defensive mobilization. Popular movements against economic adjustment policies in Latin America (Reprinted from Realidad: Revista de Ciencias Sociales y Humanidades, vol. 86, pp. 177-189, 2002). Latin American Perspectives 34: 123-139.

Alston, L.J., Libecap, G.D. \& Mueller, B. (1999) Titles, Conflict, and Land Use : the Development of Property Rights and Land Reform on the Brazilian Amazon Frontier. Ann Arbor, MI, USA: University of Michigan Press.

Anderson, A.B. (1990) Alternatives to Deforestation: Steps Tomard Sustainable Use of the Amazon Rainforest. New York, NY, USA: Columbia University Press.

Araujo, C., Bonjean, C.A., Combes, J.L., Motel, P.C. \& Reis, E.J. (2009) Property rights and deforestation in the Brazilian Amazon. Ecological Economics 68: 2461-2468.

Arcand, J.L., Guillaumont, P. \& Jeanneney, S.G. (2008) Deforestation and the real exchange rate. Fournal of Development Economics 86: 242-262.

Asner, G.P. \& Alencar, A. (2010) Drought impacts on the Amazon forest: the remote sensing perspective. New Phytologist 187: 569 578.

Baiocchi, G. (2003) Radicals in Power : the Workers' Party (PT) and Experiments in Urban Democracy in Brazil. London, UK and New York, NY, USA: ZED Books.

Baker, A. (2009) The Market and the Masses in Latin America: Policy Reform and Consumption in Liberalizing Economies. New York, NY, USA: Cambridge University Press.

Baker, D. (2003) The environmental Kuznets curve. Fournal of Economic Perspectives 17: 226-227.

Baker, I.T., Prihodko, L., Denning, A.S., Goulden, M., Miller, S. \& da Rocha, H.R. (2008) Seasonal drought stress in the Amazon: reconciling models and observations. Fournal of Geophysical Research. Biogeosciences 113: G00B01, doi:10.1029/ 2007JG000644.

Balch, J.K., Nepstad, D.C., Brando, P.M., Curran, L.M., Portela, O., de Carvalho, O. \& Lefebvre, P. (2008) Negative fire feedback in a transitional forest of southeastern Amazonia. Global Change Biology 14: 2276-2287.

Balée, W.L. \& Erickson, C.L. (2006) Time and Complexity in Historical Ecology: Studies in the Neotropical Lomlands. New York, NY, USA: Columbia University Press.

Barlow, J., Peres, C.A., Henriques, L.M.P., Stouffer, P.C. \& Wunderle, J.M. (2006) The responses of understory birds to forest fragmentation, logging and wildfires: an Amazonian synthesis. Biological Conservation 128: 182-192.

Bebbington, A. (2004) NGOs and uneven development: geographies of development intervention. Progress in Human Geography 28: $725-745$.

Bhattarai, M. \& Hammig, M. (2004) Governance, economic policy, and the Environmental Kuznets Curve for natural tropical forests. Environment and Development Economics 9: 367-382.

Borner, J. \& Wunder, S. (2007) Divergent Opportunity Costs of REDD on Private Lands in the Brazilian Amazon. CIFOR. Belém, Brazil: CIFOR.

Borner, J., Wunder, S., Wertz-Kanounnikoff, S., Tito, M.R., Pereira, L. \& Nascimento, N. (2010) Direct conservation payments in the Brazilian Amazon: scope and equity implications. Ecological Economics 69: 1272-1282.

Brannstrom, C. (2009) South America's neoliberal agricultural frontiers: places of environmental sacrifice or conservation opportunity? Ambio 38: 141-149.
Brannstrom, C., Jepson, W., Filippi, A.M., Redo, A.M., Xu, Z.W. \& Ganesh, S. (2008) Land change in the Brazilian savanna (Cerrado), 1986-2002: comparative analysis and implications for land-use policy. Land Use Policy 25: 579-595.

Bray, D.B., Ellis, E.A., Armijo-Canto, N. \& Beck, C.T. (2004) The institutional drivers of sustainable landscapes: a case study of the 'Mayan Zone' in Quintana Roo, Mexico. Land Use Policy 21: 333346.

Brondizio, E.S. (2008) The Amazon Caboclo and the Açai Palm: Forest Farmers in the Global Market. Bronx, New York, NY, USA: The New York Botanical Garden.

Brondizio, E.S. \& Moran, E.F. (2008) Human dimensions of climate change: the vulnerability of small farmers in the Amazon. Philosophical Transactions of the Royal Society B: Biological Sciences 363: 1803-1809.

Browder, J.O. \& Godfrey, B.J. (1997) Rainforest Cities: Urbanization, Development, and Globalization of the Brazilian Amazon. New York, NY, USA: Columbia University Press.

Browder, J.O., Pedlowski, M.A., Walker, R., Wynne, R.H., Summers, P.M., Abad, A., Becerra-Cordoba, M.N. \& MilHomens, J. (2008) Revisiting theories of frontier expansion in the Brazilian Amazon: a survey of the colonist farming population in Rondonia's post-frontier, 1992-2002. World Development 36: 1469-1492.

Brown, K. \& Rosendo, S. (2000) Environmentalists, rubber tappers and empowerment: the politics and economics of extractive reserves. Development and Change 31: 201-227.

Bunker, S. (1985) Underdeveloping the Amazon. Chicago, IL, USA: University of Chicago Press.

Campos, M.T. \& Nepstad, D.C. (2006) Smallholders, the Amazon's new conservationists. Conservation Biology 20: 1553-1556.

Cardenas, E. (2009) Brazilian trade dominated by four markets. World Trade Atlas [www document]. URL http://www.brazilworks. org/files/Brazil_Trade_1_.pdf

Caviglia-Harris, J.L., Chambers, D. \& Kahn, J.R. (2009) Taking the ' $U$ ' out of Kuznets. A comprehensive analysis of the EKC and environmental degradation. Ecological Economics 68: 1149-1159.

Cochrane, M.A. \& Laurance, W.F. (2008) Synergisms among fire, land use, and climate change in the Amazon. Ambio 37: 522-527.

Cole, M.A. (2003) Development, trade, and the environment: how robust is the Environmental Kuznets Curve? Environment and Development Economics 8: 557-580.

CPT (2010) Conflitos no Campo 2010. Brasilia, Brazil: CPT.

Dandy, N. (2005) Extractive reserves in Brazilian Amazonia: local resource management and the global political economy. Environmental Politics 14: 434-436.

de Araujo, M.S.M., Silva, C. \& de Campos, C.P. (2009) Land use change sector contribution to the carbon historical emissions and the sustainability: case study of the Brazilian Legal Amazon. Renemable and Sustainable Energy Reviems 13: 696-702.

Dean, M. (2010) Governmentality: Power and Rule in Modern Society. Los Angeles, CA, USA and London, UK: SAGE.

Domínguez, J.I. \& Shifter, M. (2008) Constructing Democratic Governance in Latin America. Baltimore, USA: Johns Hopkins University Press.

Dowie, M. (2009) Conservation Refugees: the Hundred Year Conflict between Global Conservation and Native People. Cambridge, MA, USA: MIT Press.

Erickson, C.L. (2006) Historical ecology of complex landscapes of the Bolivian Amazon. In: Time and Complexity in Historical Ecology, 
ed. W. Balée \& C. Erickson, pp. 235-278. New York, NY, USA: Columbia University Press.

Fearnside, P.M. (2001) Land-tenure issues as factors in environmental destruction in Brazilian Amazonia: the case of Southern Pará. World Development 29: 1361-1372.

Fearnside, P.M. (2007) Brazil's Cuiaba-Santarem (BR-163) highway: the environmental cost of paving a soybean corridor through the Amazon. Environmental Management 39: 601-614.

Fearnside, P.M. (2008) The roles and movements of actors in the deforestation of Brazilian Amazonia. Ecology and Society 13: 23 [www document]. URL http://www.ecologyandsociety.org/ vol13/iss1/art23/

Fearnside, P.M., Righi, C.A., Graca, P., Keizer, E.W.H., Cerri, C.C., Nogueira, E.M. \& Barbosa, R.I. (2009) Biomass and greenhouse-gas emissions from land-use change in Brazil's Amazonian 'arc of deforestation': the states of Mato Grosso and Rondonia. Forest Ecology and Management 258: 1968-1978.

Fleishman, E., Ray, C., Sjogren-Gulve, P., Boggs, C.L. \& Murphy, D.D. (2002) Assessing the roles of patch quality, area, and isolation in predicting metapopulation dynamics. Conservation Biology 16: 706-716.

Foresta, R.A. (1991) Amazon Conservation in the Age of Development: the Limits of Providence. Gainesville, FL, USA: University of Florida Press.

Fortes, A. (2009) In search of a post-Neoliberal paradigm: the Brazilian left and Lula's government. International Labor and Working-Class History 75: 109-125.

Foucault, M., Burchell, G., Gordon, C. \& Miller, P. (1991) The Foucault Effect: Studies in Governmentality. Chicago, IL, USA: University of Chicago Press.

Futemma, C. \& Brondizio, E.S. (2003) Land reform and landuse changes in the lower Amazon: implications for agricultural intensification. Human Ecology 31: 369-402.

Galbraith, D., Levy, P.E., Sitch, S.,. Huntingford, C., Cox, P., Williams, M. \& Meir, P. (2010) Multiple mechanisms of Amazonian forest biomass losses in three dynamic global vegetation models under climate change. New Phytologist 187: 647-665.

Glaser, B. \& Woods, W.I. (2004) Amazonian Dark Earths: Explorations in Space and Time. Berlin, Germany: SpringerVerlag.

Goeschl, T. \& Igliori, D.C. (2006) Property rights for biodiversity conservation and development: extractive reserves in the Brazilian Amazon. Development and Change 37: 427-451.

Governo do Brasil (2007) Comité Interministerial sobre Mundança de Clima. Brasilia, Brazil: Governo do Brasil.

Governo do Brasil (2008) Fontes de Recursos para Gestão Ambiental Publica. Brasilia, Brazil: Governo do Brasil.

Grainger, A. (2008) Difficulties in tracking the long term global trend in tropical forest area. Proceedings of the National Academy of Sciences USA 105: 818-823.

Greenpeace (2009) Carbon Scam: Noel Kempff Climate Action Project and the Push for Sub-national Forest Offsets. Amsterdam, the Netherlands: Greenpeace International.

Guha, R. \& Martínez Alier, J. (1998) Varieties of Environmentalism: Essays North and South. Delhi, India and New York, NY, USA: Oxford University Press.

Hall, A.L. (1997) Sustaining Amazonia: Grassroots Action for Productive Conservation. Manchester, UK and New York, NY, USA: Manchester University Press.
Hall, A.L. (2000) Amazonia at the Crossroads: the Challenge of Sustainable Development. London, UK: Institute of Latin American Studies.

Hall, A.L. (2008) Better RED than dead: paying the people for environmental services in Amazonia. Philosophical Transactions of the Royal Society B: Biological Sciences 363: 1925-1932.

Hanski, I. (2009) Theories of island biogeography and metapopulation dynamics. In: The Theory of Island Biogeography Revisited, ed. J. Losos \& R. Ricklefs, pp. 186-213. Princeton, USA: Princeton University Press.

Hayes, T.M. (2006) Parks, people, and forest protection: institutional assessment of the effectiveness of protected areas. World Development 34: 2064-2075.

Hecht, S.B. (1985) Environment, development and politics: capital accumulation and the livestock sector in Eastern Amazonia. World Development 13: 663-684.

Hecht, S.B. (1993) The logic of livestock and deforestation in Amazonia. Bioscience 43: 687-695.

Hecht, S.B. (2004) Invisible forests: the political ecology of forest resurgence in El Salvador. In: Liberation Ecologies, ed. M. Watts \& R. Peet, pp. 64-104. London, UK: Routledge.

Hecht, S.B. (2005) Soybeans, development and conservation on the Amazon frontier. Development and Change 36: 375-404.

Hecht, S.B. (2007) Factories, forests, fields and family: gender and neoliberalism in extractive reserves. Fournal of Agrarian Change 7: 316-347.

Hecht, S.B. (2009) Kayapó savanna management: fire, soils, and forest islands in a threatened biome. In: Amazonian Dark Earths: Wim Sombroek's Vision, ed. W.I. Woods, W.G. Teixeira, J. Lehmann, C. Steiner, A.M.G.A. WinklerPrins \& L. Rebellato, pp. 143-162. Heidelberg, Germany: Springer.

Hecht, S.B. (2011) New Amazonian geographies: insurgent citizenship, 'Amazon nation' and the politics of Amazon environmentalisms. Fournal of Cultural Geographies 18: 203223.

Hecht, S.B. \& Cockburn, A. (1989) The Fate of the Forest : Developers, Destroyers, and Defenders of the Amazon. New York, NY, USA: Verso.

Hecht, S.B. \& Mann, C.C. (2008) How Brazil outfarmed the American farmer. Fortune 157: 92-105.

Heckenberger, M. \& Neves, E.G. (2009) Amazonian Archaeology. Annual Reviem of Anthropology 38: 251-266.

Heckenberger, M.J., Russell, J.C., Fausto, C., Toney, J.R., Schmidt, M.J., Pereira, E., Franchetto, B. \& Kuikuro, A. (2008) PreColumbian urbanism, anthropogenic landscapes, and the future of the Amazon. Science 321: 1214-1217.

Hirsch, A.I., Little, W.S., Houghton, R.A., Scott, N.A. \& White, J.D. (2004) The net carbon flux due to deforestation and forest regrowth in the Brazilian Amazon: analysis using a process-based model. Global Change Biology 10: 908-924.

Hochstetler, K. \& Keck, M. (2007) Greening Brazil: Environmental Activism in State and Society. Durham, USA: Duke University Press.

Hoffmann, W.A., Schroeder, W. \& Jackson, R.B. (2003) Regional feedbacks among fire, climate, and tropical deforestation. Fournal of Geophysical Research-Atmospheres 108: 4721, doi:10.1029/ 2003JD003494.

Holston, J. (2008) Insurgent Citizenship: Disjunctions of Democracy and Modernity in Brazil. Princeton, NJ, USA: Princeton University Press. 
IBGE (2007) Produção da Extração Vegetal e da Silvicultura. Departamento Agropecuário, 1950-2006. Rio de Janeiro, Brazil: Instituto Brasileiro de Geografia e Estatística.

Imazon (2008) Quem é o Dono do Amazônia? Belem, Brazil: Imazon. INPE (2008) Projeto Desmatamento 1997-2007. INPE, São José dos Campos, Brazil [www document]. URL http://www.obt. inpe.br/prodes/

INPE (2011) Taxas Annuais de Desmatemento. Sao Jose dos Campos, Brazil: INPE.

Irwin, R. (2007) The neoliberal state, environmental pragmatism and its discontents. Environmental Politics 16: 643-658.

Jepson, W. (2006) Producing a modern agricultural frontier: firms and cooperatives in Eastern Mato Grosso, Brazil. Economic Geography 82: 289-316.

Joppa, L.N., Loarie, S.R. \& Pimm, S.L. (2008) On the protection of 'protected areas'. Proceedings of the National Academy of Sciences USA 105: 6673-6678.

Kant, S. (2009) Recent global trends in forest tenures. Forestry Chronicle 85: 849-858.

Killeen, T.J. (2007) A Perfect Storm in the Amazon Wilderness: Development and Conservation in the Context of the Initiative for the Integration of the Regional Infrastructure of South America (IIRSA). Arlington, USA: Conservation International.

Killeen, T.J., Douglas, M., Consiglio, T., Jorgensen, P.M. \& Mejia, J. (2007) Dry spots and wet spots in the Andean hotspot. Fournal of Biogeography 34: 1357-1373.

Klink, C.A. \& Machado, R.B. (2005) Conservation of the Brazilian Cerrado. Conservation Biology 19: 707-713.

Lara, R.J. \& Cohen, M.C.L. (2009) Palaeolimnological studies and ancient maps confirm secular climate fluctuations in Amazonia. Climatic Change 94: 399-408.

Laurance, W.F. (2002) Hyperdynamism in fragmented habitats. Fournal of Vegetation Science 13: 595-602.

Laurance, W.F. (2004) Forest-climate interactions in fragmented tropical landscapes. Philosophical Transactions of the Royal Society of London Series B: Biological Sciences 359: 345-352.

Laurance, W.F. (2007) Have we overstated the tropical biodiversity crisis? Trends in Ecology and Evolution 22: 65-70.

Laurance, W.F. (2008) Theory meets reality: how habitat fragmentation research has transcended island biogeographic theory. Biological Conservation 141: 1731-1744.

Laurance, W.F., Albernaz, A.K.M., Schroth, G., Fearnside, P.M., Bergen, S., Venticinque, E.M. \& Da Costa, C. (2002a) Predictors of deforestation in the Brazilian Amazon. Fournal of Biogeography 29: 737-748.

Laurance, W.F., Lovejoy, T.E., Vasconcelos, H.L., Bruna, E.M., Didham, R.K., Stouffer, P.C., Gascon, C., Bierregaard, R.O., Laurance, S.G. \& Sampaio, E. (2002b) Ecosystem decay of Amazonian forest fragments: a 22 -year investigation. Conservation Biology 16: 605-618.

Lees, A.C. \& Peres, C.A. (2006) Rapid avifaunal collapse along the Amazonian deforestation frontier. Biological Conservation 133: 198-211.

Lehmann, J., Kern, D.C., Glaser, B. \& Woods, W.I. (2003) Amazonian Dark Earths: Origin, Properties and Management. Dordrecht, the Netherlands: Kluwer Academic Publishers.

Lewis, S.L., Brando, P.M., Phillips, O.L., van der Heijden, G.M.F. \& Nepstad, D. (2011) The 2010 Amazon drought. Science 331: 554-554.

Lewis, S.L., Lloyd, J., Sitch, S., Mitchard, E.T.A. \& Laurance, W.F. (2009) Changing ecology of tropical forests: evidence and drivers.
Annual Reviem of Ecology Evolution and Systematics 40: 529 549.

Ludewigs, T., D'Antona, A.D., Brondizio, E.S. \& Hetrick, S. (2009) Agrarian structure and land-cover change along the lifespan of three colonization areas in the Brazilian Amazon. World Development. 37: 1348-1359.

Malhi, Y., Aragao, L., Galbraith, D., Huntingford, C., Fisher, R., Zelazowski, P., Sitch, S., McSweeney, C. \& Meir, P. (2009) Exploring the likelihood and mechanism of a climate-changeinduced dieback of the Amazon rainforest. Proceedings of the National Academy of Sciences USA 106: 20610-20615.

Marengo, J.A., Nobre, C.A., Tomasella, J., Cardoso, M.F. \& Oyama, M.D. (2008) Hydro-climatic and ecological behaviour of the drought of Amazonia in 2005. Philosophical Transactions of the Royal Society B: Biological Sciences 363: 1773-1778.

Meggers, B.J. (1994) Archaeological evidence for the impact of megaNiño events on Amazonia during the past two millennia. Climatic Change 28: 321-338.

Mertens, B., Poccard-Chapuis, R., Piketty, M.G., Lacques, A.E. \& Venturieri, A. (2002) Crossing spatial analyses and livestock economics to understand deforestation processes in the Brazilian Amazon: the case of Sao Felix do Xingu in South Pará. Agricultural Economics 27: 269-294.

Mills, J.H. \& Waite, T.A (2009) Economic prosperity, biodiversity conservation, and the environmental Kuznets curve. Ecological Economics 68: 2087-2095.

Mittermeier, R.A., Myers, N., Thomsen, J.B., da Fonseca, A.B. \& Olivieri, S. (1998) Biodiversity hotspots and major tropical wilderness areas: approaches to setting conservation priorities. Conservation Biology 12: 516-520.

Moran, E.F., Adams, R., Bakoyema, B. \& Boucek, B. (2006) Human strategies for coping with El Niño related drought in Amazonia. Climatic Change 77: 343-361.

Morton, D.C., Defries, R.S., Randerson, J.T., Giglio, L., Schroeder, W. \&. van der Werf, G.R. (2008) Agricultural intensification increases deforestation fire activity in Amazonia. Global Change Biology 14: 2262-2275.

Myers, N., Mittermeier, R.A., Mittermeier, C.G., da Fonseca, G.A.B. \& Kent, J. (2000) Biodiversity hotspots for conservation priorities. Nature 403: 853-858.

Nepstad, D., Carvalho, G., Barros, A.C., Alencar, A., Capobianco, J.P., Bishop, J., Moutinho, P., Lefebvre, P., Silva, U.L. \& Prins, E. (2001) Road paving, fire regime feedbacks, and the future of Amazon forests. Forest Ecology and Management 154: 395407.

Nepstad, D., Schwartzman, S., Bamberger, B., Santilli, M., Ray, D., Schlesinger, P., Lefebvre, P., Alencar, A., Prinz, E., Fiske, G. \& Rolla, A. (2006a) Inhibition of Amazon deforestation and fire by parks and indigenous lands. Conservation Biology 20: 65-73.

Nepstad, D., Soares, B.S., Merry, F., Lima, A., Moutinho, P., Carter, J., Bowman, M., Cattaneo, A., Rodrigues, H., Schwartzman, S., McGrath, D.G., Stickler, C.M., Lubowski, R., Piris-Cabezas, P., Rivero, S., Alencar, A., Almeida, O. \& Stella, O. (2009) The end of deforestation in the Brazilian Amazon. Science 326: 1350-1351.

Nepstad, D.C., Stickler, C.M. \& Almeida, O.T. (2006b) Globalization of the Amazon soy and beef industries: opportunities for conservation. Conservation Biology 20: 1595-1603.

Neumann, R.P. (1998) Imposing Wilderness: Struggles over Livelihood and Nature Preservation in Africa. Berkeley, CA, USA: University of California Press. 
Okereke, C. \& Dooley, K. (2010) Principles of justice in proposals and policy approaches to avoided deforestation: towards a postKyoto climate agreement. Global Environmental Change: Human and Policy Dimensions 20: 82-95.

Pacheco, P. (2009a) Agrarian reform in the Brazilian Amazon: its implications for land distribution and deforestation. World Development 37: 1337-1347.

Pacheco, P. (2009b) Smallholder livelihoods, wealth and deforestation in the eastern Amazon. Human Ecology 37: 27-41.

Padoch, C., Pinedo-Vasquez, M. \& Henderson, A. (1999) Varzea: Diversity Development and Conservation. New York, NY, USA: Columbia Press.

Parssinen, M., Schaan, D., Ranzi, A. \& Piccolo, J. (2009) PreColumbian earthworks in the Upper Purus: a complex society in Western Amazonia. Antiquity 83: 1084-1095.

Pennington, T., Lewis, G.P. \&. Ratter, J.A. (2006) Neotropical Savannas and Seasonally Dry Forests : Plant Diversity, Biogeography, and Conservation. Boca Raton, FL, USA: CRC/ Taylor \& Francis.

Peres, C.A. (2005) Why we need megareserves in Amazonia. Conservation Biology 19: 728-733.

Peres, C.A. \& Zimmerman, B. (2001) Perils in parks or parks in peril? Reconciling conservation in Amazonian reserves with and without use. Conservation Biology 15: 793-797.

Perfecto, I., Vandermeer, J. \& Wright, A. (2009) Natures Matrix: Linking Agriculture, Conservation and Food Sovereignty. London, UK: Earthscan.

Perreault, T. (2003) Changing places: transnational networks, ethnic politics, and community development in the Ecuadorian Amazon. Political Geography 22: 61-88.

Perz, S.G. (2007) Grand theory and context-specificity in the study of forest dynamics: forest transition theory and other directions. Professional Geographer 59: 105-114.

Pinedo-Vasquez, M., Hecht, S.B. \& Padoch, C. (2011) Traditional forest knowledge: sustaining communities, ecosystems and biocultural diversity in Amazonia. In: Traditional Forest Knomledge Sustaining Communities, Ecosystems and Biocultural Diversity, ed. J.A. Parrotta \& R. Trosper (in press). New York, NY, USA: Oxford University Press.

Pinedo-Vasquez, M., Zarin, D.J., Coffey, K., Padoch, C. \& Rabelo, F. (2001) Post-boom logging in Amazonia. Human Ecology 29: 219-239.

Posey, D.A. \& Balée, W.L. (1989) Resource Management in Amazonia: Indigenous and Folk Strategies. Bronx, NY, USA: New York Botanical Garden.

Potter, C., Klooster, S. \& Genovese, V. (2009) Carbon emissions from deforestation in the Brazilian Amazon Region. Biogeosciences 6: 2369-2381.

Ribeiro, M.B.N. \& Verissimo, A. (2007) Patterns and causes of deforestation in protected areas of Rondonia-Brazil. Natureza $\mathbb{E}$ Conservação 5: 103-113.

Rival, L. (2006) Amazonian historical ecologies. Fournal of the Royal Anthropological Institute 12: S79-S94.

Rival, L.M. (2002) Trekking Through History : the Huaorani of Amazonian Ecuador. New York: Columbia University Press.

Saatchi, S.S., Houghton, R.A., Alvala, R., Soares, J.V. \& Yu, Y. (2007) Distribution of aboveground live biomass in the Amazon basin. Global Change Biology 13: 816-837.
Schmink, M. \& Wood, C. (1987) The 'political ecology' of Amazonia. In: Lands at Risk in the Third World, ed. P. Little \& M. Horowitz. Boulder, CO, USA: Westview Press.

Schwartzman, S., Moreira, A. \& Nepstad, D. (2000a) Rethinking tropical forest conservation: perils in parks. Conservation Biology 14: 1351-1357.

Schwartzman, S., Nepstad, D. \& Moreira, A. (2000b) Arguing tropical forest conservation: people versus parks. Conservation Biology 14: 1370-1374.

Sears, R.R., Padoch, C. \& Pinedo-Vasquez, M. (2007) Amazon forestry tranformed: integrating knowledge for smallholder timber management in eastern Brazil. Human Ecology 35: 697707.

Siegert, F., Ruecker, G., Hinrichs, A. \& Hoffmann, A.A. (2001) Increased damage from fires in logged forests during droughts caused by El Niño. Nature 414: 437-440.

Simmons, C.S. (2004) The political economy of land conflict in the Eastern Brazilian Amazon. Annals of the Association of American Geographers 94: 183-206.

Simmons, C.S., Walker, R.T., Arima, E.Y., Aldrich, S.P. \& Caldas, M.M. (2007) The Amazon land war in the south of Pará. Annals of the Association of American Geographers 97: 567592.

Singh, R.K. \& Padung, I. (2010) Climate change, REDD and biocultural diversity: consultations and grassroots initiative with indigenous people of Arunachal Pradesh. Current Science 99: 421422.

Soares, B., Alencar, A., Nepstad, D., Cerqueira, G., Diaz, M.D.V., Rivero, S., Solorzano, L. \& Voll, C. (2004) Simulating the response of land-cover changes to road paving and governance along a major Amazon highway: the Santarem-Cuiaba corridor. Global Change Biology 10: 745-764.

Soares, B.., Nepstad, D.C., Curran, L.M., Cerqueira, G.C., Garcia, R.A., Ramos, E., Voll, C.A., McDonald, A., Lefebvre, P. \& Schlesinger, P. (2006) Modelling conservation in the Amazon basin. Nature 440: 520-523.

Stickler, C.M., Nepstad, D.C., Coe, M.T., McGrath, D.G., Rodrigues, H.O., Walker, W.S., Soares, B.S. \& Davidson, E.A. (2009) The potential ecological costs and cobenefits of REDD: a critical review and case study from the Amazon region. Global Change Biology 15: 2803-2824.

Tollefson, J. (2009) Climate: counting carbon in the Amazon. Nature 461: 1048-1052.

Treccani, G. (2007) Territórios Quilombolas. Belém, Brasil: INTERPA.

Vera-Diaz, M.D., Kaufmann, R.K., Nepstad, D.C. \& Schlesinger, P. (2008) An interdisciplinary model of soybean yield in the Amazon Basin: the climatic, edaphic, and economic determinants. Ecological Economics 65: 420-431.

Villar, J.C.E., Ronchail, J., Guyot, J.L., Cochonneau, G., Naziano, F., Lavado, W., De Oliveira, E., Pombosa, R. \& Vauchel, P. (2009) Spatio-temporal rainfall variability in the Amazon basin countries (Brazil, Peru, Bolivia, Colombia, and Ecuador). International Fournal of Climatology 29: 1574-1594.

Walker, R., Browder, J., Arima, E., Simmons, C., Pereira, R., Caldas, M., Shirota, R. \& de Zen, S. (2009) Ranching and the new global range: Amazonia in the 21st century. Geoforum 40: 732 745 . 
Wolford, W. (2005) Agrarian moral economies and neoliberalism in Brazil: competing worldviews and the state in the struggle for land. Environment and Planning A, 37, 241-261.

Woods, W.I., Teixeira, W.G., Lehmann, J., Steiner, C., WinklerPrins, A.M.G.A. \& Rebellato, L. (2009) Amazonian Dark Earths: Wim Sombroek's Vision. New York, NY, USA: Springer.
Wunder, S. (2008) Payments for environmental services and the poor: concepts and preliminary evidence. Environment and Development Economics 13: 279-297.

Zoomers, E.B. \& van denHaar, G. (2000) Current Land Policy in Latin America: Regulating Land Tenure under Neo-liberalism. Frankfurt, Germany: KIT Publishers/Iberoamericana/Vervuert Verlag. 